\title{
Heparan Sulfate Proteoglycans in Neural Development
}

\author{
神経発生におけるへパラン硫酸プロテオグリカン
}

\author{
Yamaguchi, Yu \\ The Burnham Institute, 10901 North Torrey Pines Road, La Jolla, CA 92037, USA \\ FAX: 1-619-646-3199, E-mail: yyamaguchi@burnham-inst.org
}

Key Words : axonal guidance, FGF, heparan sulfate proteoglycan, neurogenesis

\begin{abstract}
Embryonic development involves the generation of progenitor cells from proliferating stem cells, followed by migration of progenitor cells to specific sites in tissues and their differentiation into specific cell types. In the nervous system, this stereotypic developmental process proceeds more exquisitely than in any other tissues because of the highly complicated connectivities of neurons required for mature nervous system. Recent studies have revealed that heparan sulfate proteoglycans may play crucial roles in various developmental processes in the nervous system.
\end{abstract}

\section{A. Introduction}

According to Goodman and Doe (1), development of the nervous system includes the following stages: i) induction and patterning of a neuron-forming region; ii) the birth and migration of neurons and glia; iii) the generation of specific cell fates; iv) guidance of the growth cones to specific targets; v) formation of synaptic connections; vi) binding of trophic factors for survival and differentiation;vii) competitive rearrangement of functional synapses; and viii) continued synaptic plasticity. An emerging picture which is very attractive to "proteoglycanologists" is that various proteoglycans and glycosaminoglycans appear to play significant biological roles in these processes. For instance, the repulsive effect of chondroitin sulfate proteoglycans (CSPGs) on neural cell migration and axonal growth has been recognized as one of the guidance cues crucial for neural patterning. The development of almost unimaginably complicated, yet highly ordered structure of the nervous system seems to depend more highly on modulating effects of proteoglycans on growth factors and adhesion molecules than that of other tissues with simpler structures.

Studies in nonneural tissues and cells during the last decade have revealed the roles of heparan sulfate proteoglycans (HSPGs) in cell adhesion, modulation of growth factor activities, and the organization of extracellular matrix. However, until recently, evidence indicating that HSPGs play significant biological roles in neural development has been rather scarce compared to that for CSPGs. There is now increasing evidence

\section{要 約}

胎児の発生過程において増殖する幹細胞から前駆細胞が生 成され、この前駆細胞が組織内の特定部位に移動し、特定の細 胞に分化する。神経系においては、成熟した神経系が高度に複 雑なニューロンの連結を必要とするため、部位特異的な発生過 程がほかの組織より更に巧妙に行われる。最近の研究からへパ ラン硫酸プロテオグライカンが神経系の発生の諸過程において 重要な働きをしている可能性が示唆された。

A. はじめに

Goodman と Doe (1) によると神経系の発生には以下の段 階が含まれている：i）神経形成部位の誘導とパターニング、ii) 神経細胞とグリア細胞の誕生と移動、iii) 特異的細胞運命の決 定、iv) 成長円錐 (growth cone) の特定の標的への誘導、v) シナ プス形成、vi) 生存と分化のための成長因子の結合、vii) 機能的 なシナプスの競合的再配列、viii) 持続的なシナプスの可塑性。 プロテオグライカン研究者にとって興味あることはこれらの過 程においてプロテオグライカンやグライコサミノグライカンが 重要な生物学的役割を持っているらしいことである。例えば、 コンドロイチン硫酸プロテオグライカン $(\mathrm{CSPG})$ が神経細胞の 移動や軸索の伸長に反撥的な作用を持ち神経パターニングに重 要な誘導のきっかけとなっていると考えられている。想像を超 えたしかも高度に秩序だった神経系の発生は、ほかの組織にお いてよりもっと、プロテオグライカンが成長因子や接着分子の 働きを調節する作用に依存するものであろう。

過去 10 年ほどの神経組織や神経細胞の研究からへパラン 硫酸プロテオグライカン (HSPG) が細胞接着、成長因子作用の 調節、細胞外マトリックス形成に関わっていることが示されて きた。しかし最近までHSPGが神経系の発生に果たす役割につ いてはCSPG の場合のようには明らかでなかった。しかし、現 在ではHSPG も神経系の発生のいくつかの重要な過程に関与す 
indicating that HSPGs also play important roles in some of the crucial processes in neural development. In this review, I discuss the recent progresses made in our knowledge about the role of HSPGs in two aspects of neural development, namely neurogenesis and axonal guidance.

\section{B. HSPGs and Neurogenesis}

\section{B-1. Neurogenesis in Mammalian Central Nervous System}

The central nervous system (CNS) originates from neuroectoderm that forms the neural tube. The primary germinal layer in the neural tube is the ventricular zone. Anatomically, the ventricular zone is a layer facing the ventricular lumen of the neural tube and consists of a columnar epithelium called neuroepithelium. All neurons and some glial cells that forms adult brain are generated from stem cells in the ventricular zone. These stem cells are also called neural precursor cells, or more histologically, neuroepithelial cells. By definition, "stem cell" is a more stringent term than "precursor cell" (2).

Neural precursor cell can be defined as a cell that has the potential to differentiate into one of three cell types of the CNS, namely neurons, astrocytes, and oligodendrocytes, and has the capacity to generate sufficient numbers of cells to form an adult brain by self-renewal (2). On the other hand, not all glial cells derive from neural precursor cells in the embryonic ventricular zone. A secondary germinal layer called the subventricular zone generates mainly glial progenies from late embryonic stages to adulthood. Daughter cells generated from neural precursor cells but not yet committed terminal differentiation are called progenitor cells.

Neurogenesis is the process of proliferation and differentiation of neural precursor cells. Neurogenesis predominantly occurs during embryonic stages, and in most parts of the mammalian CNS, neurogenesis is complete before birth. There are a few exceptions, however. For example, neurogenesis in the external granular layer of the cerebellum occurs during early postnatal period. In the dentate gyrus and subventricular zone of rodents, neurogenesis continually occurs to adult life. The latter generates neurons which then migrate toward the olfactory bulb and differentiate into granule cells and periglomerular cells of the olfactory bulb (3).

\section{B-2. Cortical Neurogenesis}

The development of the cerebral cortex starts with the proliferation of precursor cells in the ventricular zone, followed by the migration of newly generated neurons toward the pial surface, and finally, the differentiation of neurons in the cortical plate $(4,5)$. Early in this process, the wall of neural tube is composed of a single layer of neuroepithelial cells. In other words, the entire wall of neural tube represents the ventricular zone. These neuroepithelial cells are undifferentiated precursor cells rapidly undergoing cell division. Daughter cells derived from dividing neural precursor cells position themselves out-
ることが明らかにされつつある。このリビューでは最近明らか にされた神経細胞生成、軸索の誘導という二つの神経発生過程 におけるHSPG の役割について述べる。

\section{B. HSPG と神経細胞生成}

\section{B-1. 哺乳動物中枢神経系における神経細胞生成}

中枢神経 (CNS) は神経管を形成する神経性外胚葉に由来 する。神経管中の原胚細胞層 (primary germinal layer) は脳室帯 (ventricular zone) である。解剖学的に脳室帯は神経管の脳室腔 に接し神経上皮と呼ばれる柱状の上皮からなる。成熟脳を形成 するすべての神経細胞といくらかのグリア細胞は脳室帯の幹細 胞に起源する。これらの幹細胞は神経前駆細胞、あるいは組織 学的に神経上皮細胞と呼ばれる。定義上、幹細胞は前駆細胞よ り厳密な言葉である。

神経前駆細胞はCNSにおいて神経細胞、アストロサイト、 オリゴデンドロサイトの三種類の細胞に分化する能力のある細 胞として定義付けられ、自己分裂により成熟脳を作るのに十分 な数の細胞を作り出す能力を持つ $(2)$ 。一方、すべてのグリア細 胞が胎生期の脳室帯にある神経前駆細胞に由来するわけではな い。脳室下層と呼ばれる二次胚細胞層 (secondary germinal layer) が胎生期後期および成熟期にかけて主にグリア前駆細胞を作り 出す。神経前駆細胞 (neural precursor cell) に由来した娘細胞で まだ最終分化過程にコミットしていない細胞を前駆細胞 (progenitor cell) と呼ぶ。

神経発生は神経前駆細胞が増殖分化する過程である。神経 発生はおもに胎生期に起こり、哺乳動物脳においては出生時に は完成している。数少ないがこれには例外がある。例えば、小 脳の外顆粒層における神経発生は出生後早期に起こる。觢歯族 の歯状回や脳室下層においては、神経発生は成熟動物になるま で続く。後者は神経細胞を形成しこれは嗅球に移動しそこで顆 粒細胞および周顆粒細胞を形成する (3)。

\section{B-2. 皮質の神経発生}

大脳皮質の発育は脳室層の前駆細胞が増殖することにより 始まり、これら新生の神経細胞が軟膜表面に移動し、皮質板の 神経細胞に分化する $(4 、 5)$ 。この過程の早期には、神経管壁は 一層の神経上皮細胞からなる。これは神経管壁が全部脳室層で あるといえる状態である。これらの神経上皮細胞は急速な細胞 分裂をする未分化な前駆体細胞である。分裂中の神経前駆細胞 に由来した娘細胞は脳室層の外側に位置し、最終的には中間層 と呼ばれる二番目の層を形成する。中間層は分裂後の細胞が更 
Trends in Glycoscience and Glycotechnology Vol.10 No.52 (March 1998) pp.161-173

side of the ventricular zone, eventually forming a second layer called the intermediate zone. The intermediate zone becomes thicker as more postmitotic cells migrate from the ventricular zone. Final differentiation of postmitotic neurons occurs in the cortical plate which forms superficial to the intermediate zone. In the cortical plate, neurons develop dendrites and axons to form synaptic contacts with other neurons. The cortical plate increase its thickness as development proceeds, and eventually becomes the cerebral cortex.

\section{B-3. Growth Factors Involved in the Proliferation of Neu- ral Precursor Cells}

A number of studies have demonstrated that the proliferation and differentiation of neural precursor cells require various growth factors and morphogens $(2,6,7)$. Currently accepted pictures, however, are not simple, because cultured precursor cells from different brain regions and/or ages appear to respond differently to various growth factors. For example, EGF acts as a mitogen to expand neural precuror cells derived from embryonic and adult rat striatum in sphere culture $(8,9)$. Yet, as discussed below, there is strong evidence indicating FGF2 (basic FGF) is one of the crucial growth factors for proliferation and differentiation of neural precursor cells in the developing cerebral cortex.

In situ hybridization and immunohistochemistry studies have shown that FGF2 is expressed in the embryonic brain. Detailed analyses revealed that both mRNA and protein levels of the $18 \mathrm{kDa}$ isoform of FGF2 dramatically increase during the period between E14 and E18, and then decrease after birth (1012). Such a temporal expression pattern appears to be concurrent with the peak phase of cortical neurogenesis in mouse (13). Among several isoforms of FGF2, the $18 \mathrm{kDa}$ isoform is found extracellularly, whereas the other isoforms $(22,23$, and $24 \mathrm{kDa})$ are localized in the nucleus (14). Furthermore, the neuroepithelial cells in the cortical ventricular zone express FGF2 (12). Consistent with the possibility that FGF-signaling plays a role in proliferation and differentiation of cortical precurosor cells, cortical neuroepithelium expresses various types of FGF receptors (FGFRs). Qian et al. (13) reported that the IIIc isoforms of FGFR1, 2, and 3 are expressed during the period of E10-14, while other isoforms are not detected.

As the crucial growth factor for neural precursor cells, FGF2 should be mitogenic to isolated precursor cells. Ghosh and Greenberg (15) and Vicario-Abajón et al. (16) demonstrated that FGF2 indeed promotes self-renewal of precursor cells isolated from E14 rat cortex and from E16 rat hippocampus. These results strongly suggest that FGF2 is, at least, one of the crucial mitogens for cortical precursor cells. FGF2 also promotes survival and proliferation of neuronal progenitor cells from adult brain $(17,18)$.

Recent report by Qian et al. (13) suggests that the role of FGF2 may not be just to promote proliferation. They showed
に移行することにより肥厚する。分裂後の神経細胞の最終的分 化は皮質板の中で起こりこれは中間層の外側に位置する。皮質 板の中では、神経細胞は樹状突起や軸索を伸長しほかの細胞と シナプスを形成する。皮質板は分化の進行とともに肥厚し最終 的に大脳皮質となる。

\section{B-3. 成長因子は神経前駆細胞の増殖に関与する}

神経前駆細胞の増殖と分化には成長因子や形態形成因子 (morphogen) が必要であることが示されてきた (2、6、7)。現在 一般に受け入れられている考えは単純ではなく、異なった部分 や年齢の異なる脳に由来した培養前駆細胞は異なる成長因子に 対して違った反応を示すことが知られている。例えば、上皮細 胞増殖因子 (EGF) は胎生期および成熟ラットの線状体の神経前 駆細胞を球状培養した際には細胞分裂促進物質として働くが $(8,9)$ 、以下に述べるように、線維芽細胞増殖因子 (FGF) 2、(塩 基性FGF)、が発育中の大脳皮質内神経前駆細胞の増殖と分化に 関与した重要な成長因子の一つであるという強い証拠もある。

In situ hybridization や免疫組織学的研究によるとFGF2 は胎 生期の脳に発現していることが知られている。詳細な分析の結 果によると、FGF-2 の mRNAおよび $18 \mathrm{kDa}$ のタンパクがE14か らE18にかけて急激に上昇し出生後減少する (10-12)。このよう な発現の時間的な推移はマウスにおける大脳皮質の神経発生の ピークに一致しているように見える (13)。FGFのいくつかのア イソフォームのうち、 $18 \mathrm{kDa}$ のものは細胞外に見られ、その他 のもの (22、23、および $24 \mathrm{kDa})$ は細胞核内に見られる (14)。さ らに皮質脳室層中の神経上皮細胞はFGF2 発現する (12)。こ れはFGFを介したシグナル伝達が皮質前駆細胞の増殖と分化に 関与する可能性と矛盾がない。また皮質前駆細胞は数種類の FGF受容体 (FGFR) を発現することも知られている。Qian らは (13) FGFR1、2、および3のIIIcアイソフォームがE10-14の時期 に発現されるがほかのアイソフォームは検出されないことを報 告した。

FGF2は神経前駆細胞にとって必須な成長因子であるから、 単離された前駆細胞にも細胞分裂的に働くべきである。Ghosh とGreenberg（15）およびVicario-Abajónらは (16) 実際にE16 ラット皮質およびE16ラット海馬から分離した前駆細胞は自己 再生を促進することを示した。これらの結果は、FGF2 は少なく とも皮質前駆細胞にとって重要な細胞分裂促進物質の一つであ ることを強く示している。FGF2はまた成熟動物脳からの神経前 駆細胞の生存と増殖をもたらす $(17 、 18) 。$

Qian ら (13) の最近の報告では FGF2 の役割は細胞分裂を 促進するのみではなさそうで、前駆細胞から作られた細胞の細 
that the fate of cells generated from precursor cells is dependent on the concentration of FGF2. In low FGF2 concentrations, cells derived from multipotent stem cells generate neuronal progeny, whereas at higher concentrations they generate oligodendroglial progeny (13). These results suggest that in addition to the presence of FGF2 in the environment surrounding neural precursor cells, the regulation of its effective concentration and activity may be crucial for achieving exquisitely scheduled production of various neural cell types. This notion suggests the possibility that FGF-binding HSPGs may play crucial roles in the regulation of FGF2 activity during cortical development.

\section{B-4. FGF-2 Binding Perlecan-like HSPG in Developing Cortex}

Nurcombe et al. (19) reported that the expression of FGF1 and FGF2 in developing mouse cerebral cortex is differentially regulated. The expression of FGF2 in the neuroepithelium begins at $\mathrm{E}$, whereas the expression of FGF1 becomes detectable much later around at E11. These authors demonstrated that HSPGs secreted by the E9 neuroepithelial cells preferentially bind FGF2 than FGF1, but concomitant with the beginning of FGF1 expression at E11, the neuroepithelial HSPGs change their binding preference from FGF2 to FGF1. Moreover, HSPGs isolated from E11 enhance the mitogenic activity of FGF1 on neuroepithelial cells more highly than that of FGF-2, whereas HSPGs from E9 enhance FGF-2 activity more highly than FGF1 activity (19).

They demonstrated that neuroepithelial cells secrete only a single type of HSPG which has a $45 \mathrm{kDa}$ core protein, thereby claiming that the developmental change in the binding specificity to FGFs is the result of differential glycosylation on this single HSPG (19). Antibodies raised against this HSPG showed colocalization with FGF2 in E10 mouse neuroepithelium (20).

The molecular identity of the $45 \mathrm{kDa}$ core protein has still not been completely clarified. Joseph et al. (21) reported that the amino acid sequences of tryptic peptides derived from the $45 \mathrm{kDa}$ core protein "bore significant homology" with perlecan, a basement membrane HSPG. The authors have claimed that the $45 \mathrm{kDa}$ core protein is a novel splice variant of perlecan, but this contention has not been fully substantiated by available data. For example, the data do not rule out the possibility that the $45 \mathrm{kDa}$ protein is a proteolytic fragment of perlecan itself. In any event, antibodies to this putative perlecan variant stain along the meninges and surrounding blood vessels (21), a pattern consistent with a basement membrane molecule such as perlecan. On the other hand, immunoreactivity in neuroepithelia is not very remarkable compared to the staining in these basement membranes. Thus this HSPG appears to have properties more relevant to basement membranes than to neuroepithelium. Whether this putative perlecan variant is indeed responsible for the growth regulation of
胞分化の運命はFGF2 の濃度に依存するらしい。FGF2の低い濃 度では多能性幹細胞に由来した細胞は神経系の細胞となり、高 濃度のもとではオリゴデンドログリア系の細胞となる (13)。こ れらの結果は FGF2 が神経前駆細胞の周囲環境に存在するだけ でなく、その有効濃度と活性の調節が各種の絶妙に予定された 神経細胞の生成に重要であることを示唆している。これはFGF結合性 HSPG が皮質発育の過程での FGF 活性調節に重要な働 きをしている可能性を示唆する。

\section{B-4. 皮質発育過程での FGF- 結合性、パールカン様 HSPG}

Nurcombe ら (19) は発育中のマウス大脳皮質では FGF1 と FGF2 の発現が別々に調節されていると報告している。FGF2の 神経上皮での発現はE9に始まる、一方 FGF1の発現はもっと遅 くE11に検出可能となる。これらの研究者はE9の神経上皮によ り分泌された HSPG はFGF1 より FGF2 に好んで結合するが、 E11において FGF1 が分泌される時には神経上皮細胞の作る HSPG はFGF1により強く結合するようになると報告している。 さらに、E11から得られたHSPG はFGF2 よりも FGF1 の細胞分 裂促進活性をさらに増強するが、E9から得られたHSPGはFGF1 よりも FGF2の活性をより増強する (19)。

彼らは神経上皮細胞は分子量 $45 \mathrm{kDa}$ のコアタンパクを持っ た一種類の HSPG のみを産生することから、HSPG の FGF に対 する結合性の発生過程における変化はこの一種類の HSPG の糖 合成の変化によるものだと結論した (19)。この HSPGに対して 作られた抗体はマウスのE10神経上皮において HSPG と FGF2の コローカライゼションを示した。

この分子量 $45 \mathrm{kDa}$ のコアタンパクはまだ同定されていな い。Josephら (21) は $45 \mathrm{kDa}$ のコアタンパクのトリプシン分解 ペプタイドのアミノ酸組成は基底膜 HSPG であるパールカンと ‘高いホモロジー’を持つと報告している。著者らはこの $45 \mathrm{kDa}$ のコアタンパクはパールカンの新しいスプライス変異体である と結論しているが、発表されたデータからでは完全に証明され たとはいえないだろう。ともかく、このパールカン異性体と思 われる物質に対する抗体は髄膜と周囲血管を染色し (21)、これ はパールカンのような基底膜分子として矛盾がない。一方、神 経上皮に対する免疫反応性は基底膜に対する染色と比較すると 特に著明とはいえない。従って、この HSPG は神経上皮という より基底膜分子として適切な性質を持っているように見える。 このパールカン異性体と思われる分子が本当に神経上皮細胞の 
Trends in Glycoscience and Glycotechnology Vol.10 No.52 (March 1998) pp.161-173

neuroepithelial cells should be thoroughly examined by future studies.

\section{B-5. Glypicans in Cortical Development}

Another candidate HSPGs which may play a role in neurogenesis are glypicans. Glypicans are a family of glycosylphosphatidylinositol (GPI)-linked HSPGs. Five members of glypicans (glypican-1, -2, -3, -4, and -5) have been identified in mammalian species and one in Drosophila (dally).

Different paths led to the discovery of this family of HSPGs. Glypican-1, the prototype of this family which was originally called glypican, was identified as a HSPG expressed in human fibroblasts, and its cDNA was cloned from a human fibroblast library by using a monoclonal antibody (22). Glypican-2 (cerebroglycan) was first identified by biochemical analysis as one of the major HSPGs expressed in embryonic rat brain (23). It was molecularly cloned based on peptide sequences obtained from materials purified from rat brain (24). Glypican-3 (OCI-5), the first member of the family cloned, was originally identified as one of the developmentally regulated transcript in rat intestine (25). The property of its protein products as a HSPG, however, was not initially recognized. It was later found to be a HSPG (26). Glypican-4 (K-glypican) was identified by systematic PCR-based screening of cDNAs which have homologies with glypican-1 and -3 (27). Glypican-5 was cloned from an EST (expressed sequence tag) sequence in database which showed homologies with other glypicans (28). Finally, dally was cloned from a Drosophila mutant which shows abnormalities in the control of cell division in the developing visual system (29). cDNA sequence of dally revealed that it is a member of the glypican family.

Among different families of HSPGs, the glypican family exhibits most remarkable developmental expression patterns during neural development. All five members of mammalian glypicans are expressed in the nervous system at certain stages of development. Yet their spatiotemporal expression patterns are quite distinct. Glypican-1 is widely expressed in adult brain (30, 31). Glypican-2, a nervous system-specific glypican, is mainly expressed in neurons that have just become postmitotic (24). Expression of glypican-4 in the brain is restricted to early embryonic stages and, histologically, to the ventricular zone (27). Expression of glypican-5 begins in postmitotic neurons slightly after that of glypican- 2 and before that of glypican-1 (28).

Thus, glypican family HSPGs exhibits highly differential expression pattern in developing nervous system. Comparison between the expression of glypican-2 and glypican-4, in particular, exemplifies the remarkable differential regulation of glypican expression in developing brain. Glypican-2 is widely expressed in developing nervous system, but not detected in ventricular zones in any parts of the developing CNS (24). Its mRNA becomes detectable as neurons migrate out-
成長調節に必要かどうかは将来十分に研究にされる必要がある。 B-5. 皮質発生におけるグリピカン

神経発生に関与すると思われるもうひとつのHSPGはグリ ピカンである。グリピカンは GPI (glycosylphosphatidylinositol) 結合型HSPGである。哺乳動物に5 種類 (グリピカン $-1 、-2 、-3 、-$ 4、-5）とショウジョウバエに一種類のグリピカンが見つかって いる。

このHSPGファミリーはそれぞれ異なった方法で発見され た。グリピカン -1 は、このファミリーの原形で単にグリピカン と呼ばれ、ヒト線維芽細胞に発現されるHSPG として発見され、 そのcDNA はモノクロナル抗体を使って線維芽細胞ライブラ リーから得られた (22)。グリピカン -2（cerebroglycan）は胎生 期ラット脳に発現する主要な HSPG として生化学的分析により 発見された (23)。その分子クローニングはラット脳から精製さ れたものから得られたペプタイドのアミノ酸配列をもとになさ れた (24)。グリピカン -3 (OCI-5) はラット腸において発生過程 で発現される転写産物としてこのファミリーでは最初にクロー ニングされた (25)。このタンパクがHSPGであることは当初知 られず、後にHSPGであると確認された (26)。グリピカン -4 (Kglypican) はグリピカン -1 と -4 との相同性をもとにPCR 用い たcDNAクローニングによりに見つけられた (27)。グリピカン5 はEST (expressed sequence tag) ライブラリーのデータベース からほかのグリピカンとの相同性をもとにクローン化された (28)。最後に、dallyはショウジョウバエの視覚細胞の発生過程 で細胞分裂に異状を来す変異体からクローニングされた (29)。 dallyのcDNA配列からそれがグリピカンファミリーに属するこ とが明らかになった。

異なるファミリーのHSPGのうち、グリピカンファミリー は神経発生において最も特徵的な発現様式を示す。哺乳動物の 5 種類全部のグリピカンが神経系の発生の特定の段階に発現され る。しかもその時間的空間的発現パターンはそれぞれ非常に特 徵的である。グリピカン -1 は成熟脳において広く発現されてい

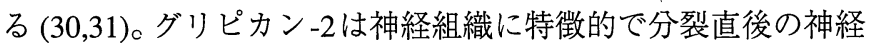
細胞に発現が見られる (24)。脳におけるグリピカン -4 の発現は 胎生早期に限られ、組織学的には脳室層に見られる (27)。グリ ピカン -5 の発現は分裂後の神経細胞でグリピカン -2 の後、グリ ピカン -1の前に見られる (28)。

このようにグリピカンファミリーは発生過程の神経系にお いて高度に区別された発現様式を示す。特にグリピカン -2 とグ リピカン-4の比較は発生中の脳でグリピカン発現が別々に調節 されているかを強調している。グリピカン -2は発生中の神経系 で広く発現されるが発生中のCNSのどの部位でも脳室層に見ら れることはない (24)。その mRNAは神経細胞が脳室層から外側 
wardly from the ventricular zone and become postmitotic. By immunohistochemistry, glypican-2 immunoreactivity is detected on axon tracts when axons are actively growing (32). In contrast, the expression of glypican-4 in the nervous system is restricted to the ventricular zones. Outer layers of the cerebral wall containing postmitotic and differentiated neurons are negative for glypican-4 expression. Little glypican-4 expression is detected in secondary germinal layers, including the subventricular zone and the external granular layer of developing cerebellum (Hagihara, K., and Y.Y.: unpublished results). Thus these two related HSPGs are differentially regulated in a highly stringent manner. These observations suggest that the functional roles of glypican- 2 and glypican- 4 in cortical neurogenesis could be distinct.

While the expression pattern of glypican-2 suggests that it may be involved in differentiation and axon elongation of postmitotic neurons, the highly restricted expression of glypican-4 in the ventricular zone suggests a role in growth regulation of neural precursor cells. The observations by in situ hybridization described above indicate that glypican-4 is expressed in replicating neural precursor cells, and that its expression is lost in postmitotic neurons. This notion is supported by in vitro studies with cultured neural precursor cells. Cells isolated from E14 rat forebrain are positively stained for nestin and are actively replicating as demonstrated by BrdU incorporation, meeting the criteria for neural precursor cells. These precursor cells are also positively stained with anti-glypican-4 antibodies (Hagihara, K. and Y.Y., manuscript in preparation). These cultures differentiate into MAP-2-positive neurons in a course of several days. The glypican- 4 immunoreactivity disappears as these cells become positive for MAP-2.

These observations suggest that glypicans, in particular glypican-4, may play important roles in cortical neurogenesis. How glypicans are involved in neurogenesis is, however, not clear at present. Yet there have recently been data suggesting at least two intriguing possibilities for glypicans to be involved in growth regulation. One possibility is that glypicans act as socalled "coreceptors" for FGF signaling. Since FGF2 is the crucial mitogen for neural precursor cells $(15,16)$, it is conceivable that glypicans expressed in the ventricular zone, most notably glypican-4, may bind FGF- and modulate its activity. How glypicans modulate FGF2 activity in the ventricular zone, whether to promote or suppress, is not clear at present. It has been reported that unlike perlecan, glypicans are rather inefficient in promoting FGF2 activity in CHO cells (33). Therefore, it is possible that FGF2 bound by glypicans may be sequestered from FGF receptors without being actively involved in FGF signaling. Such a mechanism may be important for the generation of neuronal progeny, because, as described above, the effects of FGF2 on the differentiation of neural precursor cells into different neural lineages are dependent on the concentra-
に向かって移動し細胞分裂を終えると検出されるようになる。 免疫組織化学的には、グリピカン -2 の免疫反応性は軸索が活発 に伸長している時軸索の走行に検出される (32)。一方、グリピ カン -4 の神経系での発現は脳室層にかぎられている。大脳壁外 層で分裂後の分化した神経細胞はグリピカン -4 を発現しない。 脳室下層と外顆粒層を含む二次胚細胞層にはほとんどグリピカ ン -4 は見られない (Hagihara, K., Yamaguchi, Y. 未発表データ)。 このように、これら二つのグリピカンファミリーHSPG の発現 は厳密に調節されている。これらの観察は大脳皮質の神経発生 においてグリピカン -2 と-4が異なる機能を持つことを示唆して いる。

グリピカン-2の発現パターンは分裂後神経細胞の軸索伸長 に関与していることを示唆し、脳室層に限られたグリピカン -4 の発現は神経前駆細胞の成長調節への関与を示唆する。上記の in situ hybridizationによる観察はグリピカン-4が分裂中の神経前 駆細胞により発現され分裂終了後の神経細胞では発現が中止す ることを示している。これは in vitroの神経前駆細胞の培養系で も見られる。E14のラット前脳から分離された細胞はnestinの染 色が陽性でBrdUの取り込みからさかんに細胞分裂をしているこ とが知られ、神経前駆細胞であることの基準を満足する。これ らの前駆細胞は抗グリピカン-4抗体で染色される (Hagihara, K., Yamaguchi, Y.論文準備中)。これらの培養細胞は数日中にMAP2 陽性神経細胞に分化する。グリピカン -4に対する免疫反応性 はこらの細胞がMAP-2 陽性になるにつれて消失する。

これらの観察はグリピカン、とくにグリピカン 4 五佊質の 神経形成に重要な役割を持つことを示唆する。すべてのグリピ カンがどのように神経発生に関与しているかは現時点では明ら かではない。しかしながら最近、グリピカンが成長調節に関与 しているという興味ある二つの可能性が示唆された。一つはグ リピカンがFGFを介したシグナル伝達系でいわゆる・副受容体 (coreceptor)'として機能する可能性である。FGF2は神経前駆細 胞にとって必須な細胞分裂促進因子であることから (15、16)、 脳室層に発現されるグリピカン、とくにグリピカン -4 がFGFに 結合しその活性を調節する可能性がある。脳室層においてグリ ピカンがどのように FGF2の活性を、促進的に或いは抑制的に、 調節しているかは現在明らかではない。パールカンとは異なり グリピカンは CHO 細胞において FGF2 作用を促進する作用が 十分でないという報告もある (33)。従って、グリピカンに結合 したFGF2 はFGF受容体に結合できずシグナル伝達に関与でき ない可能性もある。このような機構は、前述のように FGF2 は 濃度に依存的に神経前駆細胞に働き異なった神経系細胞への分 
Trends in Glycoscience and Glycotechnology Vol.10 No.52 (March 1998) pp.161-173

tion of FGF2 (13). The expression of glypican-4 in the ventricular zone may reduce the effective concentration of FGF2, thereby maintaining the environment which facilitates the production of neuronal progenies. Down-regulation of glypican- 4 in late embryonic to early postnatal stages may increase the effective concentration of FGF2, promoting differentiation into glial lineages. The timing of down-regulation of glypican-4, in fact, coincides with the onset of gliogenesis in the cortex.

The other possible target for growth regulation by glypicans is the signaling of bone morphogenic proteins (BMPs). There are intriguing pieces of data indicating that BMPs and glypicans are functionally linked. Genetic analyses in Drosophila have shown that there are striking similarities between dally and decapentaplegic (dpp) phenotypes and that the phenotypes of these two mutants augment together when crossed (34). These results suggest that the dally gene product, a Drosophila glypican, may be involved in the dpp signaling pathway. It is likely that mammalian glypicans may also be functionally linked to the mammalian counterparts for dpp, BMP-2 and -4. It should be noted that BMPs are implicated as a regulator in the differentiation of neural precursor cells; BMPs promote the generation of astrocytes from multipotent oligodendroglial-astroglial progenitor cells (35).

Whether glypicans act on either FGF or BMP pathway has not been elucidated. In fact, these two possibilities are not mutually exclusive; it is possible that both pathways may be regulated by glypicans. As mentioned above, results from genetic analysis in Drosophila suggest that glypicans are mainly involved in the dpp signaling pathway (34). Interestingly, Haerry et al. (36) have recently reported that in Drosophila, defect in glycosaminoglycan synthesis results in a phenotype similar to wingless, but distinct from that of dally. This suggest that the dally phenotype is due to the absence of the core protein of the dally molecule rather than that of heparan sulfate chains. Thus, these observations indicate that the core proteins of glypicans have their own function independent from heparan sulfate chains, and that such a function probably relates the modulation of the dpp signaling pathway.

With regard to the regulation of both FGF and BMP pathways in tissue development, Neubüser et al. (37) has recently made a remarkable finding which might have significant implication to glypican function. They demonstrated that the positioning of teeth along the mandibular arch is determined by antagonistic interactions between FGF and BMP pathways, and that exquisitely orchestrated regulation of both pathways is crucial for normal tissue development. In fact, it has been known that in many tissues, both FGF and BMP pathways have been shown to be involved in ordered differentiation of cells (38). With the potential to regulated both FGF and BMP signaling, glypicans may act as a dual regulator of both FGF and BMP signaling pathways.
化を起こすということから (13)、分化した神経細胞を作るため に重要かもしれない。脳室層におけるグリピカン -4 の発現は FGF2の有効濃度を減少させ、分化した神経細胞の産生を促進す るような環境を保つ働きがあるかもしれない。胎生後期から出 生後早期にかけてのグリピカン-4のダウンレギュレーションは FGF2の有効濃度を高めグリア系の細胞への分化を促進させるか もしれない。グリピカン -4 ダウンレギュレーションのタイミン グは、事実、皮質におけるグリア細胞生成の開始に一致する。

グリピカンによる成長調節のもう一つの標的はBMP (bone morphogenetic protein) によるシグナル伝達に関連している。 BMPとグリピカンが機能的に連結しているという興味あるデー 夕がある。ショウジョウバエの遺伝的分析で $\mathrm{da} 11 \mathrm{y}$ と decapentaplegic (dpp) 表現形の間に驚くほどの類似性があり、交 配されるとこれら二種類の変異体が増強し会うということが見 られた（34）。これらの結果は dally の遺伝子産物であるショウ

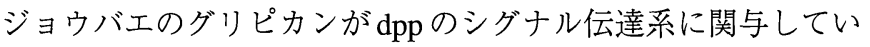
る可能性を示唆する。これは哺乳動物のグリピカンも哺乳動物 においてdppに相当するBMP-2やBMP-4の機能に関連している 可能性を示唆する。強調しておきたいのは、BMPが多能オリゴ デンドログリア - アストログリア前駆細胞からアストロサイト の生成を促進するなど、神経前駆細胞の分化調節に関連してい るらしいということである (35)。

グリピカンが実際FGF、BMPどちらの経路に働くかは明ら かではない。事実、これら二つの可能性はお互いに除外的では なく両者がグリピカンにより調節されている可能性もある。上 記のようにショウジョウバエの遺伝的な分析からはグリピカン がおもにdppのシグナル伝達に関与することが示唆された(34)。 興味深いことに、Haerryらは (36) 最近グライコサミノグライカ ン合成の欠如したショウジョウバエは wingless の表現形に似、 dallyの表現形とは異なることを報告した。これはdally表現形は dallyコアタンパクの欠如したことにより起こりへパラン硫酸の 欠如のためではないことを示している。これらの観察は、グリ ピカンのコアタンパクはヘパラン硫酸鎖に関連しない独自の機 能を持ちこれが $\mathrm{dpp}$ のシグナル伝達系の調節に関与している可 能性がある。

組織発生におけるFGF とBMP の調節については、 Neubüserら (37) が最近グリピカンの機能に深く関連すると思 われる興味深い観察をした。彼らは下顎骨弓上における歯牙の 位置はFGF と BMP の拮抗的な作用によって決定され、両者の 絶妙な統合が正常な組織形成に欠くことのできないものである ことを示した。事実多くの組織において FGF と BMP の両者が 細胞の秩序だった分化に関与することが示されている (38)。グ リピカンはFGFと BMP の両者を調節している可能性がある。 
The discovery of genetic human disorder caused by defective glypican indicates that disruption of some of glypicans may cause growth abnormalities in nervous system. The Simpson-Golabi-Behmel syndrome (SGBS) is a rare genetic disorder with overgrowth phenotype (39). It has been reported that the region containing human glypican-3 gene is disrupted in SGBS patients, indicating that glypican-3 is the causative gene of this overgrowth disorder (40). More recently, it has been demonstrated that both in human and mouse genome, the glypican-4 gene is located just next to the glypican-3 gene, suggesting that not only glypican-3 but also glypican-4 may be involved in the development of SGBS. Although not found in every case, SGBS patients sometimes show nervous system abnormalities including mental retardation and susceptibility to neuroblastoma. Expression of glypican-4 in embryonic brain and adrenal gland (27) appears to be consistent with these phenotypes. These genetic evidence, together with the striking spatiotemporal expression pattern, strongly support the possibility that glypicans, in particular glypican-4, play a crucial role in growth regulation of neural precursor cells during development.

\section{HSPGs and Axonal Guidance}

After being generated from precursor cells, nascent neurons migrate toward specific locations in developing nervous system and extend axons and dendrites making connections with other neurons. Regulation of axonal migration, or axonal guidance, is one of the most crucial steps in forming a correct neuronal network which is fundamental for brain functions. Recent studies have revealed that proteoglycans play important roles in axonal guidance. The role of CSPGs as repulsive cues against growing axons has been demonstrated in several instances in vivo, including developing retina (41) and roof plate (42). Here we will focus on the role of HSPGs in axonal guidance. While CSPGs which in general inhibit axonal growth by presenting nonpermissive substrates to growth cones, the role of HSPGs appears more complex. Recent progresses have shown that HSPGs are involved in axonal guidance, at least in part, through its regulation of FGF signaling.

\section{C-1. Perturbation of Heparan Sulfates Causes Abnormal Axonal Guidance}

Although there have been several reports showing heparan sulfates promotes neurite outgrowth in vitro (43-45), the promoting effects are not very remarkable when compared with the effects of cell-cell adhesion molecules such as N-CAM and $N$-cadherin or cell-substrate adhesion molecules such as laminin. In contrast, compelling evidence for the role of heparan sulfate in axonal guidance has been shown in several in vivo systems.

Wang and Denberg (46) used cultured cockroach embryos to study the role of glycosaminoglycans in the guidance
ヒトのグリピカン遺伝子に異常を持つ遺伝疾患の発見は、 グリピカンの異状が神経系の成長障害を来す可能性を示唆した。 Simpson-Golabi-Behmel 症候群 (SGBS) はまれな遺伝疾患で過 剩成長を示す (39)。SGBS の患者ではグリピカン -3を含むの遺 伝子の中断が見られ、グリピカン -3がこの過剩成長の原因遺伝 子であることが示された (40)。さらに最近では、ヒトとマウス のゲノムにおいてグリピカン -4はグリピカン-3のすぐ隣に位置 していることが示され、グリピカン -3 だけでなくグリピカン -4 もSGBS に関与する可能性が示唆された。すべての症例にでは ないが、SGBSの患者にはときに知能障害、神経芽細胞腫などの 神経系異常が見られる。胎生期脳および副腎におけるグリピカ ン -4の発現はこのような表現形に矛盾しないように見える。こ のような遺伝学的な証拠は、これらの時空間的な発現パターン とともに、グリピカン、とりわけグリピカン -4 が発生過程で神 経前駆細胞の成長調節に必須な働きをしていることを示唆する。

\section{HSPG と軸索誘道}

前駆細胞から生じた初期神経細胞は発生中の神経系の特定 の場所に向かって移動し、軸索と樹状突起を伸長し、ほかの神 経細胞と連絡を形成する。軸索移動の調節、或いは軸索誘導は 脳の基本的機能に必須である正しい神経網の形成にとって最も 重要である。最近の研究でプロテオグライカンが軸索誘導にお いて重要な役割を果たすことが知られた。CSPG は伸長してい る軸索に対して反撥的な働きを持つことが発生中の網膜(41)や 蓋板 (42) などいくつかの in vivoの系でその例が示された。本 論文ではHSPG の軸索誘導における働きに焦点を当てる。一般 にCSPG が成長円錐にとって非許容的な基質を提示して軸索伸 長を抑制するのに反して、HSPGの役割はもっと複雑である。最 近 HSPG が軸索誘導に関与し、少なくともその一部はFGFのシ グナル伝達を介してであることが示された。

\section{C-1. ヘパラン硫酸の変化は軸索誘導に異常を来す}

ヘパラン硫酸が in vitroで神経突起の伸長を促進するという 報告がいくつかあるが(43-45)、この促進作用は細胞間接着分子 である N-CAM や N-カドヘリンの作用や細胞 - 基質接着分子で あるラミニンなどほど著明ではない。一方、ヘパラン硫酸の軸 索誘導における役割はいくつかの in vivo の系で説得力のある証 拠が報告されている。

Wang と Denberg (46) は培養胎生ゴキブリを用いてパイオ ニア軸索の誘導におけるグライコサミノグライカンの働きを研 
Trends in Glycoscience and Glycotechnology Vol.10 No.52 (March 1998) pp.161-173

of pioneer axons. In insects, the major axonal pathways consist of two longitudinal connectives, the anterior commissure and the posterior commissure, and the median fiber tract. They found that exogenously added heparin and heparan sulfates cause pathfinding errors in the median fiber tract and the Ti1 axons, the first axon pathway in the peripheral nervous system. Similar effects were also observed in heparitinase-treated embryos. No effects were observed either with exogenously added chondroitin sulfates, dermatan sulfate, keratan sulfate, and hyaluronic acid, or with treatment with chondroitinase or hyaluronidase. The pathfinding errors observed in the embryo include misdirected growth and defasciculation of axons. Heparin/heparan sulfate did not have effects on the length of axons. Interestingly, the effect of heparin/heparan sulfate and heparitinase is pathway-specific; pathways other than the median fiber tract and the Ti1 axons are not affected by these treatments. This has been the first strong evidence for the role of heparan sulfate proteoglycans in axonal guidance.

More recently, the role of heparan sulfates in axonal guidance has also been demonstrated using developing Xenopus visual system. The developmental process of the connection between the retina and the brain provides an excellent system to study the axonal guidance. The formation of correct retinotectal projection includes remarkable complexities which are believed to be based on a highly stringent molecular guidance mechanism. Briefly, retinal ganglion cells extend axons along the inner surface of the retina toward the optic nerve. After entering the optic nerve, retinal axons continue to grow along the optic nerve into the brain through the optic chiasm. At the optic chiasm, some axons cross the chiasm entering the opposite side of the brain, whereas the others go strainght entering the same side of the brain. How axons decide whether or not to cross the chiasm is one of the most intriguing questions of axonal guidance. After passing the optic chiasm, axons grow toward the optic tectum, which is located in the dorsal side of the midbrain. Once arrived at the tectum, axons derived from different regions of the retina are targeted to different regions in the tectum and then form synaptic connections with specific tectal neurons (38).

Walz et al. (47) utilized the Xenopus system to study the effect of heparan sulfate on this guidance event. They found that heparan sulfate, when exogenously added to the developing Xenopus retinotectal pathway, prevents retinal axons to enter the tectum. Interestingly, this "bypass phenotype" appears to be dependent on the FGF2 binding activity of heparan sulfates. A heparan sulfate population which preferentially binds FGF2 causes aberrant targeting, whereas another heparan sulfate population which preferentially binds FGF1 does not. Phenotype caused by the removal of endogenous heparan sulfates by heparitinase digestion is similar to that by exogenously added heparan sulfate, but somewhat more complicated. While
究した。昆虫においては主たる軸索経路は、前交連、後交連と 中部線維路 (median fiber tract) からなる、体軸方向の二つの結 合体である。培養系にヘパリン或いはヘパラン硫酸を加えると、 中部線維路および末梢神経系での最初の軸索経路である Ti1 軸 索に走行異状を来す。同じような異状は胎児をへパリチネース で処理した時にもみられる。コンドロイチン硫酸、デルマタン 硫酸、ケラタン硫酸、ヒアルロン酸を加えたりコンドロイチ ネースやヒアルロニデースで処理した時にはこのような効果は 見られなかった。この実験で見られた神経経路探索異状は成長 方向の誤り、軸索束の崩壞などである。ヘパリン、ヘパラン硫 酸を加えても軸索の長さには影響がなかった。興味あることに、 ヘパリン、ヘパラン硫酸、ヘパリチネースの作用は経路特異的 であって、中央線維（median fiber）およびTi1 軸索以外には影 響が見られなかった。これがヘパラン硫酸プロテオグライカン が軸索誘導に関与しているという最初の強い証拠である。

$$
\text { もっと最近には、発生中のアフリカツメガエル視覚系をも }
$$
ちいてへパラン硫酸の軸索誘導における役割が示された。網膜 と脳の間の連結を形成する発生過程は軸索誘導の分析に有用な 系を提供する。正しい網膜 - 被蓋連結を形成するためには非常 に厳密な分子誘導機構に基づく複雑な過程が必要であると信 じられている。手短かに言うと、網膜結節細胞 (retinal ganglion cells)は網膜の内側に沿って視神経の方向に軸索を伸長する。視 神経に進入すると網膜からの軸索は視神経に沿って伸び視交叉 を通って脳に達する。視交叉ではいくつかの軸索は対側の脳に 達し、あるものは同側の脳に達する。視交叉を越えた後軸索は 中脳の背側に位置した被蓋に向かう。被蓋に到達すると、網膜 の異なる部位から来た軸索は被蓋の異なる部位を標的として特 定の被蓋細胞とシナプスを形成する (38)。

Walz ら (47) はアフリカツメガエルの系を用いてへパラン 硫酸のこの誘導過程に対する影響を研究した。彼らはヘパラン 硫酸を発生中アフリカツメガエルの網膜 - 被蓋経路の系にに加 えると、網膜からの軸索が被蓋に進入するのを抑制するのを見 つけた。興味あることには、この“バイパス表現形”はへパラ ン硫酸の FGF 結合性に依存するらしい。FGF2 に結合性の高い ヘパラン硫酸は異常な標的方向を来すが FGF1 結合性のへパラ ン硫酸はこのような作用を持たない。ヘパリチネースを使った 内因性ヘパラン硫酸の消化実験は外からへパラン硫酸を加えた 場合と似ているがが、幾分複雑な結果であった。軸索が視神経 
heparitinase treatment after axons have extended through the optic tract causes the bypass phenotype as in the case with exogenously added haparan sulfates, treatment at the beginning of optic tract formation inhibits the growth of axons, an effect not found by exogenously added heparan sulfates. These findings suggest that heparan sulfates are involved in the regulation of both axonal growth and guidance, possibly by two distinct mechanisms.

\section{C-2. Possible Mechanism of Axonal Guidance by Heparan Sulfates}

The aforementioned results by Walz et al. (47) suggest that the role of heparan sulfates on axonal growth and guidance in the Xenopus visual system may be mediated by their involvement in the FGF signaling system. In fact, there have been a number of reports indicating FGFs may be involved in neurite outgrowth in vitro and axonal guidance in vivo. McFarlane et al. (48) have shown using the same Xenopus visual system that FGF2 is present in developing optic tract and that the growth cones of retinal ganglion cells express FGF receptors. FGF2 stimulates neurite extension of retinal neurons in vitro and causes mistargeting of retinal axons when applied exogenously to the developing optic pathway (48). Furthermore, retinal ganglion cells which had been transfected with a dominant negative FGF receptors in vivo can extend axons along the normal retinotectal route, but are incapable of entering the tectum and forming connection with appropriate tectal neurons (49). These findings indicate that the activation of FGF-R in the growth cone is required for proper target recognition of retinal axons and that tectal border represents the site for the change in FGF-R signaling. In this vein, it is interesting to note that Saffell et al. (50) demonstrated that activation of FGF$\mathrm{R}$ is necessary for neurons to extend neurites in response to homophylic adhesion caused by NCAM, N-cadherin, and L1. Thus, there are strong pieces of evidence indicating that activation of FGF-R system is a crucial element for axonal growth and target recognition.

The phenotype of Xenopus retinotectal projection caused by dominant negative FGF-R or by exogenously added FGF2 clearly overlaps with those caused by exogenously added heparan sulfates or by heparitinase treatment. This suggests that heparan sulfates may be a part of FGF-R activation mechanism during axonal guidance. Heparan sulfates binds not only FGFs but also their receptors (51-53). Therefore, the involvement of heparan sulfates in the FGF-R signaling pathway may be either through their binding to FGFs or to FGF-Rs. These two possibilities are not mutually exclusive; heparan sulfates may be modulating both ligands and receptors at the same time.

Finally, there is a possibility that heparan sulfates may have effects on axonal guidance independent from the FGF/ FGF-R signaling. A number of cell-cell and cell-substrate adhesion molecules in the nervous system bind heparin/heparan
に進入後にヘパリチネース処理をすると外からへパラン硫酸を 加えたときのように'バイパス表現形'を示すが、視経路を形成 する初期からへパリチネース処理をすると軸索の伸長が抑制さ れ、これは外からへパラン硫酸を加えた場合には見られない。 これらの観察はへパラン硫酸がおそらく違った機構で軸索の成 長と誘導の双方に関与していることを示唆する。

\section{C-2. ヘパラン硫酸による軸索誘導の機構について}

前述のWalzら (47) による報告は、ヘパラン硫酸がアフリ カツメガエル視覚系において軸索の成長とその誘導に役割は FGFのシグナル伝達系に関わることによることを示唆している。 事実、FGFが in vitroでの神経突起の伸長や in vivo での軸索誘 導に関与している報告はいくつもある。McFarlane ら (48) は同 ビアフリカツメガエル視覚系を用いて FGF2 が発生中の視神経 路に存在し網膜結節細胞の成長円錐がFGF受容体を発現するこ とを示した。FGF2 は in vitroで網膜細胞の神経突起伸長を促進 し、これを発生中の視神経路に外的に加えると網膜軸索の標的 誤認を来す (48)。さらに、in vivoでドミナントネガティブFGF 受容体をトランスフェクトされた網膜結節細胞は軸索を正常な 網膜 - 被蓋経路に沿って伸長するが被蓋に進入して適切な被蓋 神経細胞と連絡を作ることができない (49)。これらの所見は成 長円錐におけるFGF受容体の活性化は網膜軸索による正しい標 的の認識に必要であり、被蓋の境界がFGF受容体のシグナル系 の変化部位であることを示唆している。同様に、Saffell ら (50) 神経細胞がNCAM、N-カドヘリン、L1を介したホモフィリッ クな接着をする際に神経突起を伸長する反応にFGF受容体の活 性化が必要であることを示したのも興味がある。このように、 FGF受容体の活性化が軸索の伸長と標的認識に重要であるらし い強い証拠が挙げられている。

アフリカツメガエルにドミナントネガティブFGF受容体を 発現させた場合或いはFGF2 を外部から加えた場合に見られる 表現形は外部からへパラン硫酸やへパリチネースを加えた場合 と共通点が見られる。これはへパラン硫酸が軸索誘導における FGF 受容体活性化機構の一部となっている可能性を示唆する。 ヘパラン硫酸は FGF だけでなく FGF 受容体にも結合する $(51-$ 53)。したがって、ヘパラン硫酸のFGF受容体シグナル伝達系に おける役割はこれがFGFあるいはFGF受容体に結合するためで あろう。この二つの可能性はお互いに排除的ではなく、へパラ ン硫酸が同時にライガンドと受容体の両方を調節しているのか もしれない。

終わりに、ヘパラン硫酸がFGF/FGF受容体のシグナル伝達 系を介さずに軸索誘導に影響を持つ可能性について述べたい。 神経系にあるいくつかの細胞間および細胞 - 基質接着分子はへ 
Trends in Glycoscience and Glycotechnology Vol.10 No.52 (March 1998) pp.161-173

sulfate (54). Therefore, heparan sulfates may act as ligand or receptor for these adhesion molecules, thereby affecting axonal guidance.

\section{C-3.Molecular Species of HSPGs Involved in the Retino- tectal Projection}

Which HSPG(s) is involved in the axonal guidance in the Xenopus retinotectal projection has not been elucidated. The putative perlecan variant described above (21) is a possible candidate for such a HSPG, since the FGF2-binding heparan sulfate chains that cause the bypass phenotype (6) were prepared from this HSPG (55). Indeed, the localization of the perlecan variant appears to fit this model better than the model in which this HSPG plays a role in growth control of neuroepithelial cells. As described above, this molecule is found in the basement membrane along pial surfaces more abundantly than in neuroepithelium itself (21). The route of axon elongation in the retinotectal projection corresponds to this location. Functionally, among various HSPGs, perlecan is the most efficient HSPG in promoting FGF2/FGF-R binding (31), which again seems consistent with this model. Syndecans are another candidate which may be involved in axonal guidance. It has been shown that syndecan- 2 is expressed in the diencephalon/midbrain boundary, an important region for neural patterning, in Xenopus embryo (56).

\section{Concluding Remarks}

It has become clear from genetic and developmental studies that HSPGs are crucial component for embryonic development including that of the nervous system. Comparing with CSPGs which generally act as inhibitory substrates for cell adhesion and neurite outgrowth, the biological effect of HSPGs in neural development appears multilateral and its mechanism of action more complicated. Yet, as discussed in this review, their role in the modulation of growth factors and morphogens will be the focus of research during the next several years to come.

Although not discussed in this review, the role of HSPGs in the nervous system is certainly not limited to the developmental aspects. There are at least two additional aspects in which HSPGs are suspected to play important roles in the nervous system; one is their role in synaptic cell adhesion, and the other is their role in neurodegenerative diseases. For example, Schubert (57) proposed a model of synaptic plasticity in which heparan sulfates might regulate the strength of synaptic cell adhesion. With regard to their role in neurodegenerative diseases, Goedert et al. (58) have demonstrated that heparan sulfates facilitate the formation of neurofibrillary tangles, a hallmark for Alzheimer's disease, and that heparan sulfates are deposited in the brain of Alzheimer patients. Thus studies on HSPGs will generate important information as to developmental and pathophysiological aspects of the nervous system in coming years.
パリン/ヘパラン硫酸に結合する (54)。したがって、ヘパラン 硫酸はこれらの接着分子に対してライガンド或いは受容体と なって働き、軸索誘導に影響を与える可能性がある。

\section{C-3. 網膜 - 被蓋神経路に関与する HSPG}

アフリカツメガエルの網膜 - 被蓋神経路の軸索誘導にどの HSPG が関与しているかは明らかになっていない。上記のパー ルカンの異性体と推定される HSPG (21) は一つの可能性であ る、なぜならば'バイパス表現形 (6) 'を来す FGF2 結合性のへ パラン硫酸鎖はこのHSPG から得られたものである (55) からで ある。事実パールカン異性体の分布はHSPG が神経上皮細胞の 成長調節に働くというモデルよりもこのモデルに良く適合する。 上記のようにこの分子は神経上皮細胞よりも軟膜表面に沿った 基底膜に多く見られる (21)。網膜 - 被蓋放射における軸索伸長 の経路はこの部位に相当する。機能的にも、各種の HSPG の中 でパールカンがもっとも FGF2/FGF 受容体結合を促進し (31)、 これもこのモデルに適合するように見える。シンデカンは軸索 誘導に関与している可能性のあるもう一つの候補である。シン デカン-2がアフリカツメガエルの神経パターニングに重要な部 位である間脳/中脳境界部に発現しているとの報告がある (56)。

\section{D. 結 語}

遺伝学的および発生学的研究から、HSPG が神経系を含む 胎児発生に欠くことのできない要素であることは明らかである。 一般に細胞接着や神経突起伸長に抑制的な働きを持つ CSPG と 比較すると、HSPG の神経発生における生物学的役割は多面的 で作用機構は複雑であるように見える。しかし、このリビュー で議論されたようにそれらが成長因子や形態形成因子の作用を 調節する役割が今後数年にわたっても研究の焦点となるであろ う。

このリビューでは述べられなかったが、もちろん神経系に おけるHSPGの役割は発生学的な側面に限られたものではない。 神経系において重要と考えられる少なくとも二つのHSPG の機 能が挙げられる; 一つはシナプス性細胞接着における役割で、 もう一つは神経の変成疾患における役割である。例えば、 Schubert (57) はへパラン硫酸がシナプス性細胞接着の強度を調 節している可能性のあるところのシナプスの可塑性についての モデルを提出した。神経系の変成疾患に関する役割としては、 Goedert ら (58) がアルツハイマー病の特徵である神経線維の㨝 れの形成をへパラン硫酸が促進し、アルッハイマー病患者の脳 組織にへパラン硫酸が沈着していると報告した。このようにへ パラン硫酸に関する研究は将来にわたって神経系の発生学的、 生理学的側面に関する重要な情報を提供するであろう。

\section{東京医科歯科大学歯学部生化学講座}

\section{柳下 正樹訳}


Trends in Glycoscience and Glycotechnology Vol.10 No.52 (March 1998) pp.161-173

\section{References}

1. Goodman, C.S., and Doe, C.Q. (1993) in The Development of Drosophila melanogaster (Bate, M., and Martinez Arias, A.,eds.) pp. 11311206, Cold Spring Harbor, NY, Cold Spring Harbor Press

2. McKay, R. (1997) Science 276, 66-71

3. Luskin, M.B. (1993) Neuron 11, 173-189

4. Rakic, P. (1974) Science 183, 425-427

5. Jacobson, M. (1991) Developmental Neurobiology, 3rd Edition, New York, Plenum Press

6. Weiss, S., Reynolds, B.A., Vescovi, A.L., Morshead, C., Craig, C.G., and van der Kooy, D. (1996) Trends. Neurosci. 19, 387-393

7. Stemple, D.L., and Mahanthappa, N.K. (1997) Neuron 18, 1-4

8. Reynolds, B.A. and Weiss, S. (1992) Science 255, 1707-1710

9. Reynolds, B.A., and Weiss, S. (1996) Dev. Biol. 175, 1-13

10. Powell, P.P., Finkelstein, S.P., Dionne, C.A., Jaye, M., and Klagsbrun, M. (1991) Mol. Brain Res. 11, 71-77

11. Giordano, S., Sherman, L., Lyman, W., and Morrison, R. (1992) Dev. Biol. 152, 293-303

12. Weiss, B., Janet, T., and Grothe, C. (1993) J. Neurosci. Res. 34, 442-453

13. Qian, X., Davis, A.A., Goderie, S.K., and Temple, S. (1997) Neuron 18, 81-93

14. Mason, I. (1994) Cell 78, 547-552

15. Ghosh, A. and Greenberg, M.E. (1995) Neuron 15, 89-103

16. Vicario-Abajón, C., Johe, K.K., Hazel, T.G., Collazo, D., and McKay, R.D.G. (1995) Neuron 15, 105-114

17. Gage, F.H., Coates, P.W., Palmer, T.D., Kuhn, H.G., Fisher, L.J., Suhonen, J.O., Peterson, D.A., Suhr, S.T., and Ray, J. (1995) Proc. Natl. Acad. Sci. USA 92, 11879-11883

18. Gritti, A., Parati, E.A., Cova, L., Frolichsthal, P., Galli, R., Wanke, E., Faravelli, L., Morassutti, D.J., Roisen, F., Nickel, D.D., and Vescovi, A.L. (1996) J. Neurosci. 16, 1091-1100

19. Nurcombe, V., Ford, M.D., Wildschut, J.A., and Bartlett, P.F. (1993) Science 260, 103-106

20. Ford, M.D., Bartlett, P.F. and Nurcombe, V. (1994) NeuroReport 5, 565-568

21. Joseph, S.J., Ford, M.D., Barth, C., Portbury, S., tlett, P.F., Nurcombe, V., and Greferath, U. (1996) Development 122, 3443-3453

22. David, G., Lories, V., Decock, B., Marynen, P., Cassiman, J.-J., and Van den Berghe, H. (1990) J. Cell Biol. 111, 3165-3176

23. Herndon, M.E., and Lander, A.D. (1990) Neuron 4, 949-961

24. Stipp, C.S., Litwack, E.D., and Lander, A.D. (1993) J. Cell. Biol. 124, 149-160

25. Filmus, J., Church, J.G., and Buick, R.N. (1988) Mol. Cell. Biol. 8, 4243-4249

26. Filmus, J., Shi, W., Wong, Z.M., and Wong, M.J. (1995) Biochem. J. 311, 561-565

27. Watanabe, K., Yamada, H., and Yamaguchi, Y. (1995) J. Cell Biol. 130, 1207-1218

28. Saunders, S., Paine-Saunders, S., and Lander, A.D. (1997) Dev. Biol. 190, 78-93

29. Nakato, H., Futch, T.A., and Selleck, S.B. (1995) Development 121, 3687-3702

30. Karthikeyan, L., Flad, M., Engel, M., Neyer-Puttlitz, B., Margolis, R.U., and Margolis, R.K. (1994) J. Cell Sci. 107, 3213-3222

31. Litwack, E.D., Stipp, C.S., Kumbasar, A., and Lander, A.D. (1994) J. Neurosci. 14, 3713-3724

32. Ivins, J.K., Litwack, E.D., Kumbasar, A., Stipp, C.S., and Lander, A.D. (1997) Dev. Biol. 184, 320-332

33. Aviezer, D., Hecht, D., Safran, M., Eisinger, M., David, G., and Yayon, A. (1994) Cell 79, 1005-1013

34. Jackson, S.M., Nakato, H., Suriura, M., Jannuzi, A., Oakes, R., Kaluza, V., Golden, C., and Selleck, S.B. (1997) Development 124, 41134120

35. Mehler, M.F., Mabie, P.C., Zhang, D., and Kessler, J.A. (1997) Trends. Neurosci. 20, 309-317

36. Haerry, T.E., Heslip, T.R., March, J.L., and O'Connor, M.B. (1997) Development 124, 3055-3064

37. Neubüser, A. Peters, H., Balling, R., and Martin, G.R. (1997) Cell 90, 247-255

38. Gilbert, S.F. (1997) Developmental Biology, 5th ed., Sunderland, Massachusetts,Sinauer Associates, Inc.

39. Weksberg, R., Squire, J.A., and Templeton, D.M. (1996) Glypicans: a growing trend. Nature Genet. 12, $225-227$.

40. Pilia, G., Hughes-Benzie, R.M., MacKenzie, A., Baybayan, P., Chen, E.Y., Huber, R., Neri, G., Cao, A., Forabosco, A., and Schlessinger, D. (1996) Nature Genet. 12, 241-247

41. Brittis, P.A., Canning, D.R., and Silver, J. (1992) Science 225, 733-736

42. Oakley, R.A., and Tosney, K.W. (1991) Dev. Biol. 147,187-206

43. Lafont, F., Rouget, M., Triller, A., Prochiantz, A., and Rousselet, A. (1992) Development 114, 17-29

44. Stenger, D.A., Pike, C.J., Hickman, J.J., and Cotman, C.W. (1993) Brain Res. 630, 136-147

45. Sugiura, M., and Dow, K.E. (1994) Dev. Biol. 164, 102-110

46. Wang, L., and Denburg, J.L. (1992) Neuron 8, 7701-714

47. Walz, A., McFarlane, S., Brickman, Y.G., Nurcombe, V., Bartlett, P.F., and Holt, C.E. (1997) Development 124, 2421-2430

48. McFarlane, S., Mcneill, L., and Holt, C.E. (1995) Neuron 15, 1017-1028

49. McFarlane, S., Cornel, E., Amaya, E., and Holt, C.E. (1996) Neuron 17, 245-254

50. Saffell, J.L., Williams, E.J., Mason, I.J., Walsh, F.S., and Doherty, P. (1997) Neuron 18, 231-242

51. Kan, M. Wang, F., Xu, J., Crabb, J.W., Hou, J., and McKeehan, W.L. (1993) Science 259, 1918-1921

52. Gao, G. and Goldfarb, M. (1995) EMBO J. 14, 2183-2190

53. Seddon, A.P., Aviezer, D., Li, L.Y., Bohlen, P., and Yayon, A. (1995) Biochemistry 34, 731-736

54. Lander, A.D. (1989) Trends Neurosci. 12, 189-195

55. Brickman, Y.G., Ford, M.D., Small, D.H., Bartlett, P.F., and Nurcombe, V. (1995) J. Biol. Chem. 270, 24941-24948

56. Teel, A.L. and Yost, H.J. (1996) Mech. Dev. 59, 115-127

57. Schubert, D. (1991) Trends Neurosci. 14, 127-130

58. Goedert, M., Jakes, R., Spillantini, M.G., Hasegawa, M., Smith, M.J., and Crowther, R.A. (1996) Nature 383, 550-553 


\section{Profile of the Author}

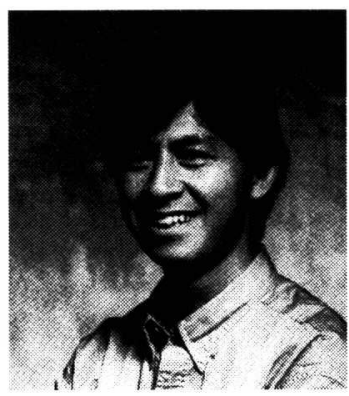

Yu Yamaguchi

B or n a nd raised in Sendai, $\mathrm{J}$ a p a n, Y u . Yamaguchi graduated from Tohoku University of School of Medicine in 1981. After graduation, he entered the graduate program in Department of Obstetrics and Gynecology at Tohoku University. Spending most of his time during graduate school in Department of Biochemistry (Prof. Zensaku Yosizawa) at the same university, he received a degree of Doctor of Medical Sciences with work on structural and functional properties of fetal fibronectins (thesis advisor: Prof. Mamoru Isemura). In 1985, he joined Dr. Erkki Ruoslahti's laboratory at the La Jolla Cancer Research Foundation (currently The Burnham Institute) and worked on the problem of growth factor-proteoglycan interactions.

After appointed to faculty at the same institute, he has been focusing on brain proteoglycans. Currently, he is an Associate Professor in the Neurobiology Program at the Burnham Institute. 